\title{
Nesting patterns among Neotropical species assemblages: can reserves in urban areas be failing to protect anurans?
}

\author{
Ricardo Lourenço-de-Moraes ${ }^{1,2}$ (1) • Leo R. Malagoli ${ }^{3}$. Vinicius Guerra ${ }^{2} \cdot$ Rodrigo B. Ferreira $^{4}$ • \\ Igor de Paiva Affonso ${ }^{2,5} \cdot$ Célio F. B. Haddad ${ }^{6} \cdot$ Ricardo J. Sawaya $^{7} \cdot$ Rogério P. Bastos $^{1}$
}

Published online: 16 June 2018

(C) Springer Science+Business Media, LLC, part of Springer Nature 2018

\begin{abstract}
Nestedness among species assemblages implies that sites of lower species richness are subsets of richer sites in a regional species pool. This nestedness is a reflection of a non-random process of species loss as a consequence of factors that promote the disaggregation of assemblages. The impoverishment of assemblage diversity is more often observed in fragmented landscapes. This non-random process has important implications for conservation. We recorded 95 species of anurans across 22 protected areas, of which 11 sites were in an urban matrix and 11 were in a non-urban matrix. We found that sites in the urban matrix had lower richness and high values of nestedness with no spatial autocorrelation among geographic distances and species composition. Thus, species were non-randomly distributed across the landscape and a nested pattern was documented from non-urban matrix sites to urban matrix sites. The impoverishment of assemblages toward the urban matrix sites may suggest that protected areas in an urban matrix are less suitable for anuran conservation than those in a non-urban matrix sites. Both the ecological revitalization of protected areas in urban matrix and protection of non-urban forested sites are needed for the conservation of Neotropical anurans.
\end{abstract}

Keywords Fragmentation $\cdot$ Atlantic Forest $\cdot$ Biodiversity $\cdot$ Hotspot $\cdot$ Metacommunities

\section{Introduction}

Community ecology focuses on the patterns and mechanisms responsible for the distribution of organisms and diversity in space and time (Cadotte et al. 2006; Moore and Swihart 2007). In this sense, a set of communities connected by

Electronic supplementary material The online version of this article (https://doi.org/10.1007/s11252-018-0767-5) contains supplementary material, which is available to authorized users.

Ricardo Lourenço-de-Moraes ricardo_lmoraes@hotmail.com

1 Departamento de Ecologia, Laboratório de Herpetologia e Comportamento Animal, Universidade Federal de Goiás (UFG), 74001-970, Cx. Postal 131, Goiânia, GO, Brazil

2 Programa de Pós-Graduação em Ecologia de Ambientes Aquáticos Continentais, Universidade Estadual de Maringá (UEM), Maringá, PR 87020-900, Brazil

3 Programa de Pós-Graduação em Ciências Biológicas (Zoologia), Laboratório de Herpetologia, Departamento de Zoologia e Centro de Aquicultura (CAUNESP), Instituto de Biociências, Universidade Estadual Paulista (UNESP), Rio Claro, SP 13506-970, Brazil dispersion is called a metacommunity (Gilpin and Hanski 1991; Wilson 1992; Leibold et al. 2004), and the distribution of nested species subsets is an ecological component of metacommunity theory (Leibold and Mikkelson 2002). Nested species assemblages occur when biotas of sites with low species richness are subsets of biotas at richer sites

4 Programa de Pós-Graduação em Ecologia de Ecossistemas, Universidade Vila Velha (UVV), Vila Velha, ES 29102-770, Brazil

5 Departamento de Ciências Biológicas, Universidade Tecnológica Federal do Paraná, Campus Ponta Grossa, Av. Monteiro Lobato, S/N, Km 04, Ponta Grossa, PR 84016-210, Brazil

6 Departamento de Zoologia e Centro de Aquicultura (CAUNESP), Instituto de Biociências, Universidade Estadual Paulista (UNESP), Rio Claro, SP 13506-970, Brazil

Centro de Ciências Naturais e Humanas, Universidade Federal do ABC (UFABC), São Bernardo do Campo, SP 09606-070, Brazil 
(Wright and Reeves 1992; Ulrich and Gotelli 2007; Baselga 2010). The impoverishment of assemblage diversity is more often observed in fragmented landscapes, indicating that species loss is not a random process (Gaston and Blackburn 2000).

Nested distributions may result from differences in species attributes, such as area required, abundance, and tolerance to abiotic variables (Cook and Quinn 1998; Almeida-Neto et al. 2008). Most sites in an urban matrix do not fulfill the requirements of most species, which can promote local extinction (Patterson and Atmar 1986) and/or selective colonization (Cook and Quinn 1995). Although the local dynamics of colonization and extinction can vary over a range of habitats (Taylor and Warren 2001), nestedness analyses have traditionally been conducted on large systems such as islands and mountain ranges (e.g., Patterson and Atmar 1986; Lomolino 1996, 2000; Morrison 2013), which may exhibit patterns indicative of high levels of non-random assemblage organization. The concept of nestedness has been fundamental to understanding the effects of anthropogenic actions in a variety of landscapes (Watling and Donnelly 2007; Watling et al. 2009). Nesting patterns have been reported for fragmented environments (Rocha et al. 2014). The evaluation of nestedness over a gradient from urban to non-urban sites may promote a better understanding of how to manage urban biodiversity.

Brazil has the greatest diversity of amphibians in the world (Segalla et al. 2016) with approximately $50 \%$ of its occurring species in the Atlantic Forest (Haddad et al. 2013). Because this biome is considered one of the world's hotspots for biodiversity conservation due its high species diversity and endemism (Mittermeier et al. 2004; Rödder et al. 2007), studying anurans over an urban matrix gradient of Atlantic Forest remnants may offer a good model for conservation policies. Understanding the scale at which impacts occur is critical to the successful conservation of amphibians in urbanized landscapes (e.g., ecological corridors), because it can effectively guide conservation efforts.

Amphibians are sensitive to anthropogenic changes, even inside protected areas (Lambert 1997; Lips and Donnelly 2002; Becker et al. 2007; Francis and Barber 2013). They are the most threatened vertebrate group (Stuart et al. 2004; Wells 2007; Hoffmann et al. 2010) and are considered bioindicators of environmental quality (Wells 2007). Studies investigating amphibian community structure through cooccurrence and nestedness analyses (e.g., Tockner et al. 2006; Watling et al. 2009; Moreira and Maltchik 2012) have shown that anuran distribution patterns are related to area and isolation and their associated processes (Tockner et al. 2006; Watling et al. 2009).

Considering that the effects of urbanization should impose extinction on original assemblages, we hypothesized that anuran communities will exhibit nested patterns of species composition from sites in urban matrix toward sites in non-urban matrix. To test this hypothesis, we surveyed the frog assemblages of 22 forest fragments in urban and non-urban matrix sites and analyzed the species composition of anurans among them. We aimed to understand: (i) if the distance between sites influences community composition, (ii) how species are distributed among sites (composition and richness), and (iii) if the proximity to urban environments influences anuran species richness. We aim to raise awareness of amphibian sensibility to anthropic environments.

\section{Methods}

\section{Study sites}

We conducted the study in the Atlantic Forest biome that has latitudinal range extending into the tropical and subtropical regions (Olson et al. 2001; Ribeiro et al. 2009). The longitudinal range of Atlantic Forest favors differences in forest composition due to a diminishing gradient in rainfall from coast (i.e., east, more rainy) to interior (i.e., west, less rainy) (Ribeiro et al. 2009).

To verify that the tested hypothesis are not influenced by forest formation, two areas were studied inside of Atlantic Forest biome both with distinct formation forest types (Fig. 1): 1) Municipality of Maringá, state of Paraná, according to Köppen-Geiger's climate system (Maack 1981; Peel et al. 2007), is classified as Cfb (humid temperate climate with temperate summer) with mean temperatures of $17.7^{\circ} \mathrm{C}$ and mean annual rainfall of $1276 \mathrm{~mm}$; it is located in the western part of the biome (Figs. 1 and 2), with formations of warmer and seasonal forests (Olson et al. 2001); and 2) municipality of São Paulo, state of São Paulo is classified as Cwa (humid temperate climate with dry winter and hot summer) with mean temperatures of $18.5^{\circ} \mathrm{C}$ and mean annual rainfall of $1340 \mathrm{~mm}$, well distributed throughout the year (Peel et al. 2007); it is located in the eastern region of biome (Figs. 1 and 2), with non-seasonal rainforest formations (Olson et al. 2001).

\section{Spatial species data}

Our work was focused on 22 protected areas (PAs) from two municipalities of Brazilian Atlantic Forest (Fig. 1). The protected areas were chosen following three conditions proposed for the occurrence of nesting patterns: i) a common biogeographical history, ii) similarity of composition among habitats, and iii) a hierarchical relationship of niches (e.g., presence of specialist and generalist species, see Patterson and Brown 1991). In the municipality of Maringá (23 $25^{\prime} \mathrm{S}$, $51^{\circ} 55^{\prime} \mathrm{W}$ ) (Fig. 2), we sampled four urban matrix PAs and six non-urban matrix PAs between 2005 and 2016. In the munic-

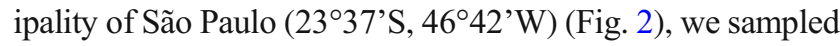




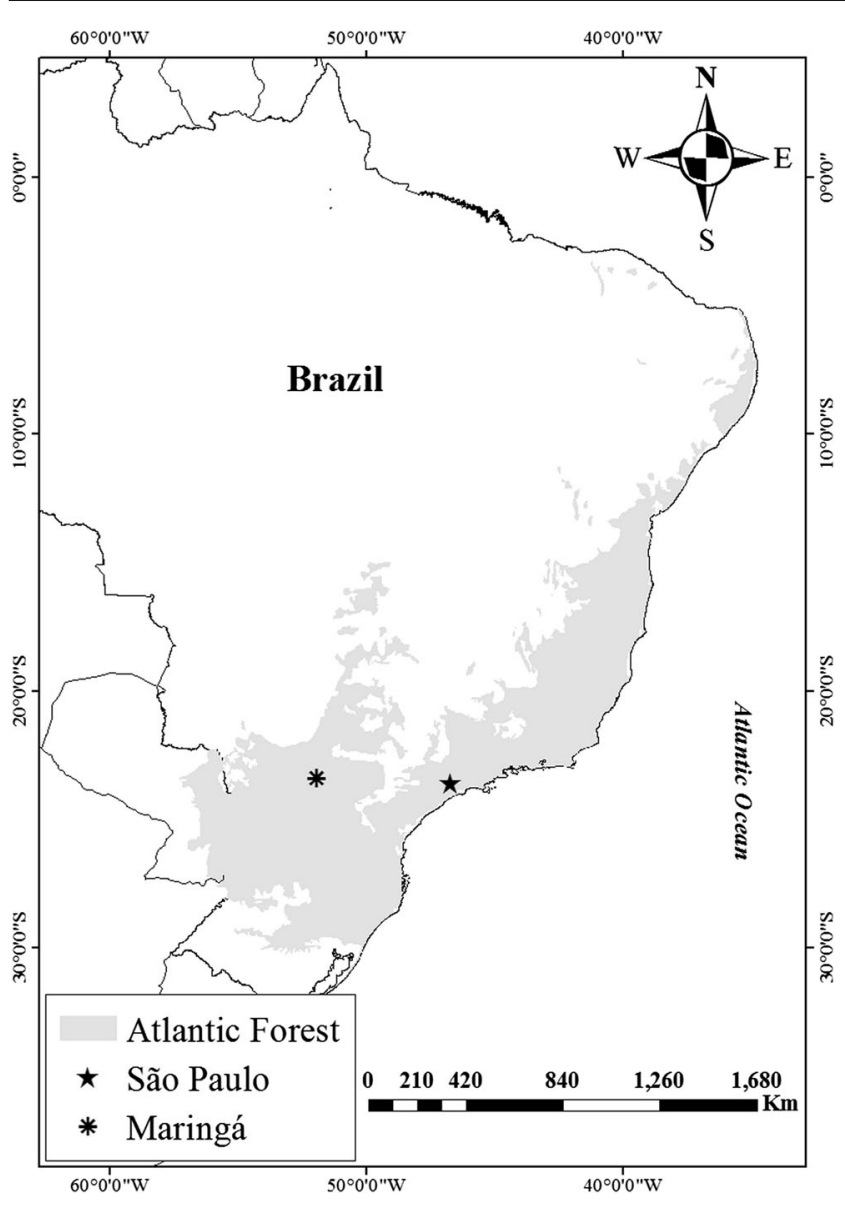

Fig. 1 Location of studied areas in the Brazilian Atlantic Forest (gray)

seven urban matrix PAs and five non-urban matrix PAs between 1996 and 2017.

We evaluated the effect of urbanization on PAs by determining the oldest urbanized areas of both municipalities. The PAs were classified according to "time of urbanization": i) oldest urbanized area (i.e., $>50$ years of urbanization); ii) periphery of urban matrix (i.e., <50 years of urbanization); and iii) non-urban matrix (see Fig. 2). The time of urbanization was determined according to data available at official websites from both municipalities (Maringá: http://www2.maringa.pr. gov.br/site/ and São Paulo: http://www.capital.sp.gov.br/). We assumed that anurans from PAs within the oldest urbanized area were more prone to the effects of urbanization (e.g., reduction of gene flow with other populations).

To compile data on species richness for each selected PA, we adopted three procedures: i) fieldwork by the authors, ii) bibliographic records, and iii) search in zoological collections. The anurans were sampled using pitfall traps with drift fences in 14 PAs (Corn 1994), and with acoustic and visual nocturnal and diurnal surveys in all available habitats (e.g., water bodies, leaflitter and bromeliads) and along $100 \mathrm{~m}$ forest transects in 22 PAs (Crump and Scott Jr 1994; Zimmerman 1994). In addition, the data were also complemented from information available in the literature and visits to three zoological collections
(Museu de Zoologia da Universidade de São Paulo MZUSP, Museu de Zoologia da Universidade Estadual de Campinas - ZUEC, and Coleção "Célio F. B. Haddad" Universidade Estadual Paulista - CFBH).

The urban matrix PAs were more sampled to have the maximum information about the species richness. For the details of the methods and data sources for each area see Supplementary Material 1.

We used the Red List of threatened species of the International Union for Conservation of Nature (IUCN 2016) for assessing the conservation status of species. The taxonomic nomenclature followed Frost (2017).

\section{Data analysis}

We used the Mantel test to assess the relationship between geographic distance (i.e., degree of isolation of sites) and species composition among sites (Legendre and Fortin 1989). The $Z$ statistic calculated by the Mantel test indicates the degree of spatial correlation among the data. The test was performed by correlating a dissimilarity matrix (Euclidian distance) with a matrix of species presence or absence (Jaccard). A total of 1000 permutations were performed for null models (Legendre and Anderson 1999).

We used a null model analysis with the c-score index to explore the pattern of species co-occurrence and to test whether the distribution is random or due to interspecific interaction mechanisms (i.e., biotic and abiotic interactions) (Gotelli and Graves 1996). An equiprobable-equiprobable null model with 1000 simulations was implemented by randomizing species occurrence and assuming that species occurrences in environments were equally likely, that is, equal probabilities for each species to occur in each environment (Gotelli and Graves 1996).

We calculated a nestedness metric based on overlap and decreasing fill (index NODF) (Almeida-Neto et al. 2008; Ulrich et al. 2009) to determine if the spatial pattern among communities is nested, as well as to verify if there is a nested gradient from the non-urban matrix toward the urban matrix. According to this nestdness metric, two basic properties are required to have the maximum degree of nestedness: (i) complete overlap of 1's from right to left and from down to up rows, and (ii) marginal decreasing totals between all pairs of columns and all pairs of rows. The nestedness statistic is evaluated separately for columns ( $\mathrm{N}$ columns), and rows ( $\mathrm{N}$ rows), and combined for the whole matrix (NODF). The columns of species are ordered according to their presence in sites (species that occurs in all sites is ordered in the first column), rows are ordered according to the species richness in each site. These procedures create a gradient allowing to evaluate the sites that provide species for a subset of species/sites, forming a nested pattern. We used null models to test whether the generated values differ from those expected at random. 


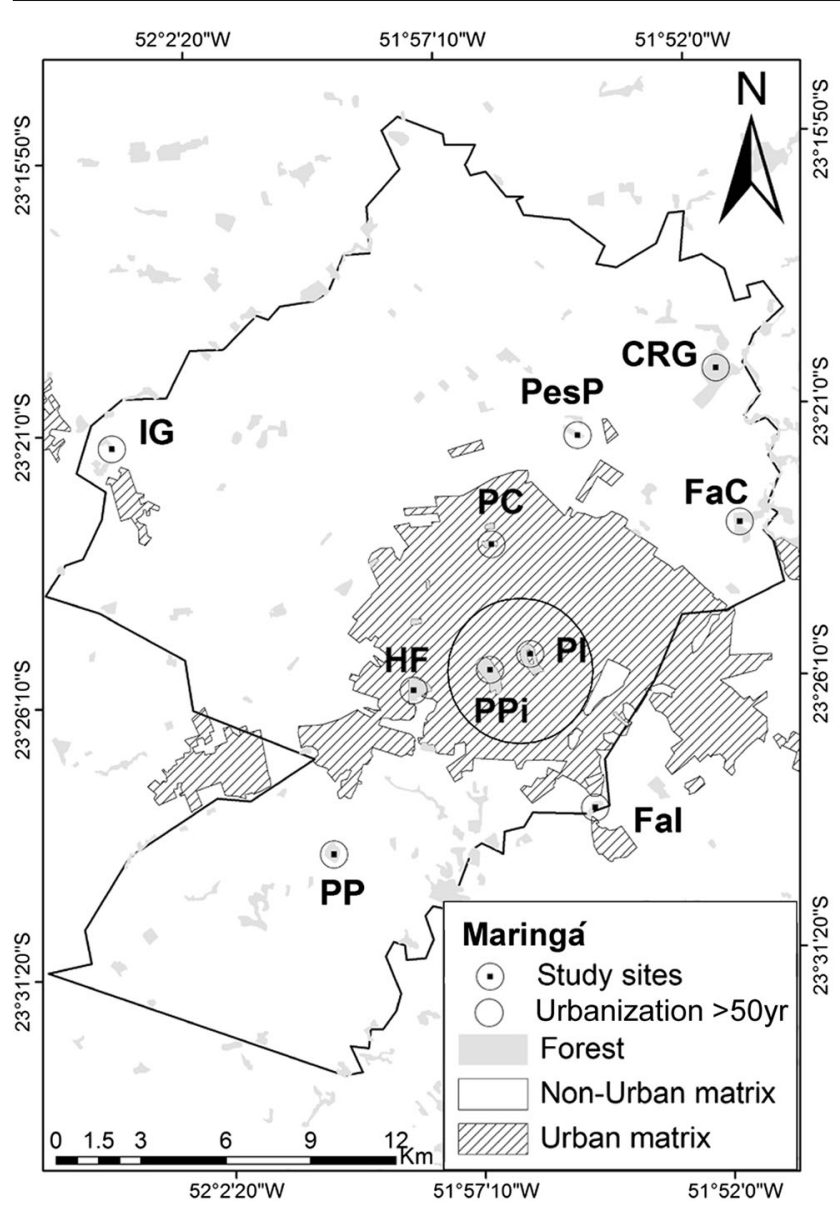

Fig. 2 Location of study sites in the municipality of Maringá and São Paulo (Black line). Study sites: $\mathrm{FaC}=$ Fazenda Cesumar; $\mathrm{PP}=$ Parque das Perobas; $\mathrm{IG}=$ Iguatemi; $\mathrm{PC}=$ Parque do Cinquentenário $; \mathrm{FaI}=$ Fazenda Ibiteca; $\mathrm{CRG}=$ Condomínio Recanto dos Guerreiros; PesP $=$ Pesqueiro do Português; $\mathrm{HF}=$ Horto Florestal; $\mathrm{PPi}=$ Parque dos Pioneiros; PI = Parque do Ingá. São Paulo study sites: PAn = Parque Anhanguera; $\mathrm{PEC}=$ Parque Estadual da Cantareira; $\mathrm{PEAL}=$ Parque Estadual Alberto

The null models randomize the occurrence of the taxa between the sites sampled, keeping fixed the sums of the columns (species). To perform this analysis, original matrices were submitted to 1000 simulations.

To evaluate the nesting effects of sites with higher species richness towards the sites with smaller species richness, we partitioned beta diversity into two separate components of species, turnover and nestedness-resultant dissimilarities (Baselga 2010). This method partitions the pairwise Sørensen dissimilarity between two communities ( $\beta$ sor) into two additive components accounting for species spatial turnover ( $\beta$ sim) and nestedness-resultant dissimilarities ( $\beta$ sne). Since $\beta$ sor and $\beta$ sim are equal in the absence of nestedness, their difference is a net measure of the nestedness-resultant component of beta diversity, so $\beta$ sne $=\beta$ sor $-\beta$ sim $($ Baselga 2010). We used the function 'beta.pair' that returns three matrices containing the pairwise between-site values of each component of beta diversity (Baselga and Orme 2012).

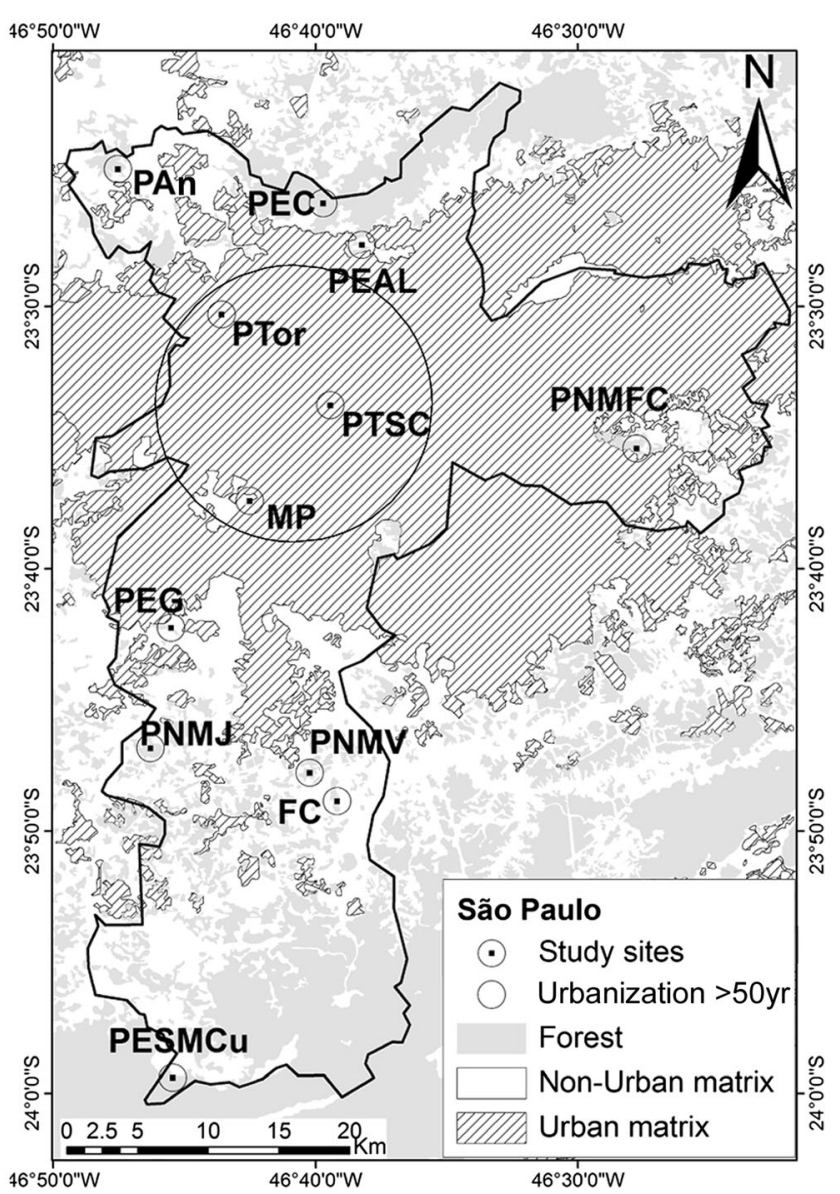

Löfgren "Horto Florestal"; PTor $=$ Parque Cidade de Toronto; PTSC $=$ Parque Tentente Siqueira Campos "Trianon MASP"; PNMFC = Parque Natural Municipal Fazenda do Carmo; MP = Marginal Pinheiros - Área do Projeto Pomar; $\mathrm{PEG}=$ Parque Ecológico Guarapiranga; $\mathrm{PNMJ}=$ Parque Natural Municipal Jaceguava; PNMV = Parque Natural Municipal Varginha; FC $=$ Fazenda Castanheiras; $P E S M C u=$ Parque Estadual da Serra do Mar - Núcleo Curucutu

We followed the gradient provided by NODF index for analysis of beta diversity partitioning. Only the values of ßsne are presented (mean, standard deviation, higher and lower value), under the effect of nestedness the first major and second major biota provided by NODF at all sites.

To test whether a negative species gradient with increasing $\beta$ sne values occurs (increased nesting decreased species richness), we used a simple linear regression between the larger biota provided by index NODF and all sites (subset). To test whether the total area of PAs is significantly different between urban and non-urban matrices, we used Mann-Whitney Test after evaluating data normality using Shapiro test. We also used these statistical tests to evaluate a gradient of species richness between PAs from the urban matrix to the nonurban matrix, in the three urbanization time periods (see above). We performed analyses for both localities separately using the package 'vegan' (Oksanen et al. 2007) and 'betapart' package (Baselga and Orme 2012) in R (R Development Core Team 2017). 


\section{Results}

We recorded 95 species of which 27 were from Maringá, 81 from São Paulo, and 13 common to both localities (Supplementary Material 2, 3, and 4). Regarding conservation status, we found the Near Threatened Crossodactylus schmidti in Maringá and the Critically Endangered Bokermannohyla izecksohni in São Paulo. The other species are listed in either Least Concern (LC) or Data Deficient (DD) categories (see Supplementary Material 3 and 4 for more details).

In Maringá, we found 20 species at urban matrix sites and 26 species at non-urban matrix sites. In São Paulo, we found 30 species in urban matrix sites and 76 species at non-urban matrix sites. In Maringá, $8 \%$ of the species were found in forest areas (2 spp), 65\% at forest edges (18 spp), and $27 \%$ in open areas (7 spp). In São Paulo, 53\% of the species were found in forest areas (43 spp), 30\% at forest edges (24 spp), and 17\% in open areas (14 spp) (see Supplementary Material 2).

The Mantel test showed no spatial autocorrelation among geographic distances and species composition across sites (Maringá: $r=-0.26, p=0.92$; São Paulo: $r=0.27, p=$ 0.12 ). The $c$-score index was greater than expected by chance (Maringá: $C$-score $=1.35, p=0.0009$; São Paulo: $C$-score $=$ $1.45, p=0.0009$ ), indicating a pattern of non-random species composition across sites within both localities.

The NODF index indicated that the communities from both localities exhibited nested patterns (Maringá: $p=0.0009$; São Paulo: $p=0.0009$ ), with a ratio of 75 and filling matrix of $51.1 \%$ for Maringá and a ratio of 44 and filling matrix of $22.5 \%$ for São Paulo (Fig. 3a, b and Table 1). In the species occurrence matrix, we observed a trend to fill the upper left portion, featuring an upper triangular matrix (Fig. 3a, b).

The results of the betapart analysis indicated higher nesting values in urban matrix, and decreasing towards the non-urban matrix. The analysis for Maringá sites indicated $\beta$ sne mean of $0.26 \pm 0.26(0.02-0.83)$ for PP (large biota) vs. all sites (subset) and $\beta$ sne mean of $0.24 \pm 0.25(0.02-0.82)$ for $\mathrm{FaC}$ (large biota) vs. all sites (subset). São Paulo sites indicated $\beta$ sne mean of $0.48 \pm 0.24(0.10-0.96)$ for PESMCu (large biota) vs. all sites (subset) and $\beta$ sne mean $0.24 \pm 0.16(0.00-$ $0.56)$ for PEC (large biota) vs. all sites (subset). The nesting values between the two largest biotas of both localities are low, for Maringá PP vs. FaC 0.02 and São Paulo PESMCu vs. PEC 0.10 (see Fig. 4a-d).

The linear regression of richness vs. nestedness indicated highly significant values of species richness loss and increase of nesting values towards the urban matrix sites (Maringá $R^{2}=0.85, p<0.001$; São Paulo $R^{2}=0.74, p<0.001$ see Fig. 5). The total area of PAs in urban matrix did not differ from PAs in non-urban matrix (Maringá $\mathrm{W}=71.5, p=0.259$; São Paulo $\mathrm{W}=27.0, p=0.149$ ). Species richness differed between PAs in urban matrix to PAs in non-urban matrix
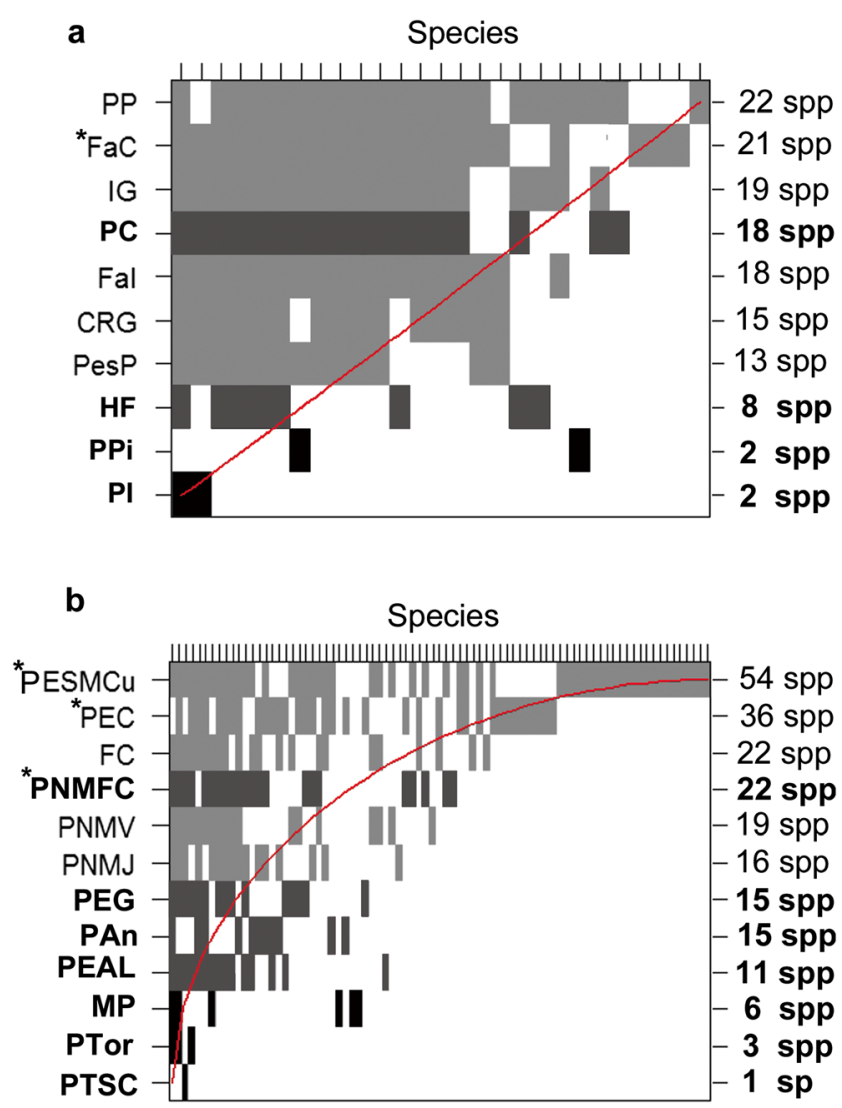

Fig. 3 Matrix of presence (filled cells) and absence (empty cells) of anuran species from sampling sites in Maringá (a) and São Paulo (b). The red line represents the isocline of differences in species richness among PAs. The black bars show the PAs in oldest urbanized area (i.e., $>50$ years), darkest gray bars the PAs in periphery of urban matrix (i.e., $<50$ years), and gray bars show the PAs in non-urban matrix. (*) indicates presence of threatened species, PAs in bold indicates presence in urban matrix

(Maringá $\mathrm{W}=86.0, p=0.006$; São Paulo $\mathrm{W}=131.5, p$ $<0.001$ see Fig. 6).

\section{Discussion}

Our results revealed a nested pattern of anurans from the nonurban matrix sites toward the urban matrix sites, urban matrix

Table 1 Results generated by the analysis of nestedness metric based on overlap and decreasing fill (NODF) in different study sites. The nestedness statistic is evaluated separately for columns ( $\mathrm{N}$ columns), for rows ( $\mathrm{N}$ rows) and combined for the whole matrix (NODF)

NODF Index

\begin{tabular}{lllll}
\hline & Maringá & \multicolumn{3}{l}{ São Paulo } \\
\hline N columns & 75.2 & $p=0.0009$ & 47.5 & $p=0.0009$ \\
N rows & 76.0 & $p=0.0009$ & 62.1 & $p=0.0009$ \\
NODF & 75.3 & $p=0.0009$ & 47.7 & $p=0.0009$ \\
Matrix fill & $51.1 \%$ & & $22.5 \%$ & \\
\hline
\end{tabular}




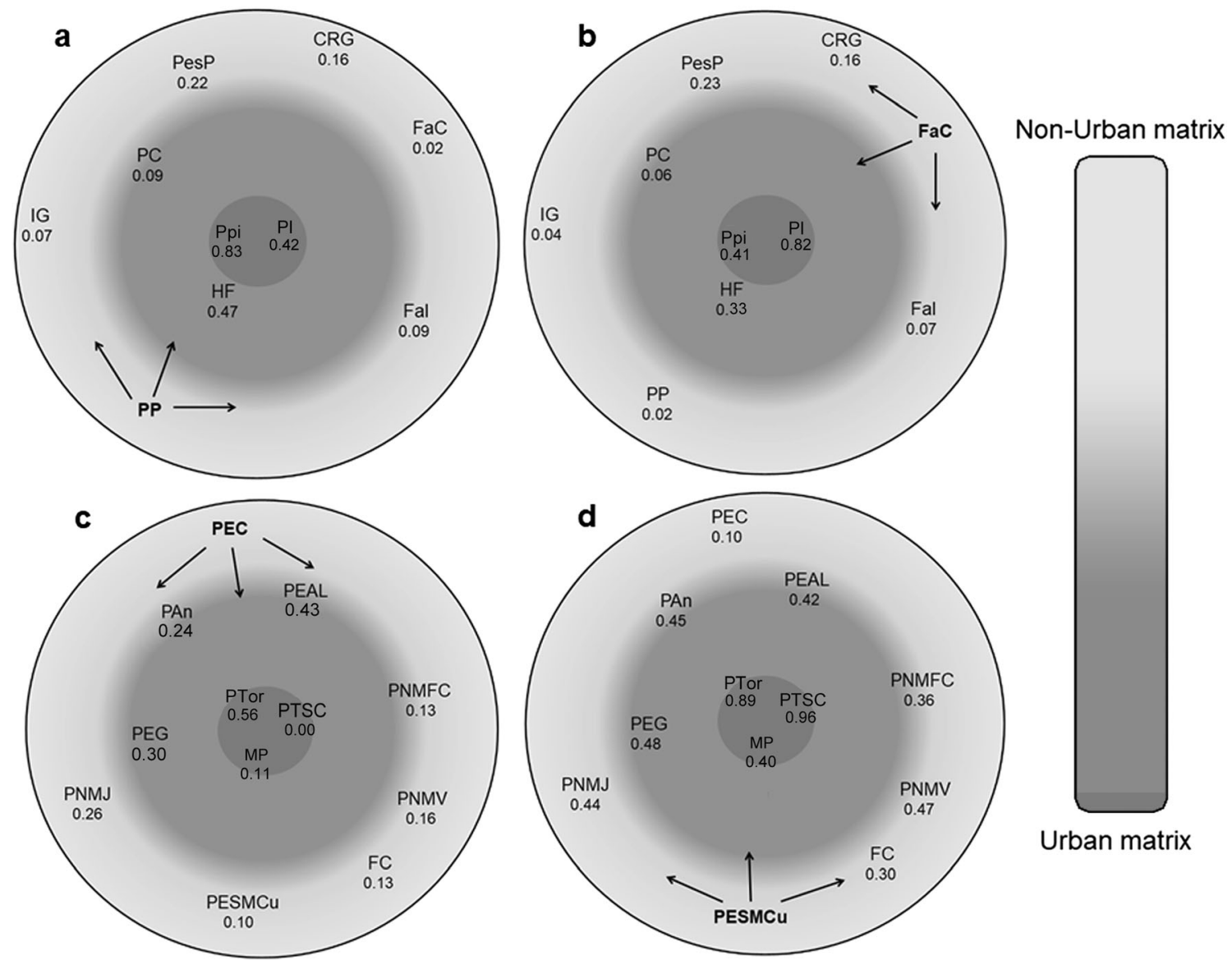

Fig. 4 Scheme in which the layout of the parks is based on their location on the map (Fig. 2). Betapart values ( $\beta$ sne) of studied sites at Maringá (a, b) and São Paulo (c, d). The betapart analyzes regards the NODF ordering. (a) show the nesting values of PP and (d) PESMCu (in bold) for the

sites are subsets of non-urban matrix sites. This pattern is similar in both types of forest formations (Maringá: warmer and seasonal forest; São Paulo: non-seasonal forest). The NODF values for Maringá indicated by the isoclines of differences in species richness (Fig. 3), showed that nestedness is better distributed and species richness gradually decrease. In São Paulo the NODF values indicated by isoclines that nestedness is influenced by high values of PESMCu, because other sites (arrows); (b) show the nesting values of $\mathrm{FaC}$ and (c) PEC (in bold) in relation to the other areas (arrows). The urbanization time is in the legend indicated by the coloration of light gray (no effect) for the darkest gray ( $>50$ years)

of high species richness in relation to the others PAs. The urban matrix sites had poorer species richness toward the non-urban matrix sites. However, two areas located in the periphery of the urban matrix (PC and PNMFC) showed species richness similar to smaller areas in non-urban matrix. These areas seem to be less affected by urbanization, which allows more species to remain. The Mantel test indicated that the distance between sites does not influence
Fig. 5 Simple linear regressions between (a) species richness and nesting values (PP) and (b) species richness and nesting values (PESMCu). The black points show the PAs in non-urban matrix; red squares show PAs in urban matrix
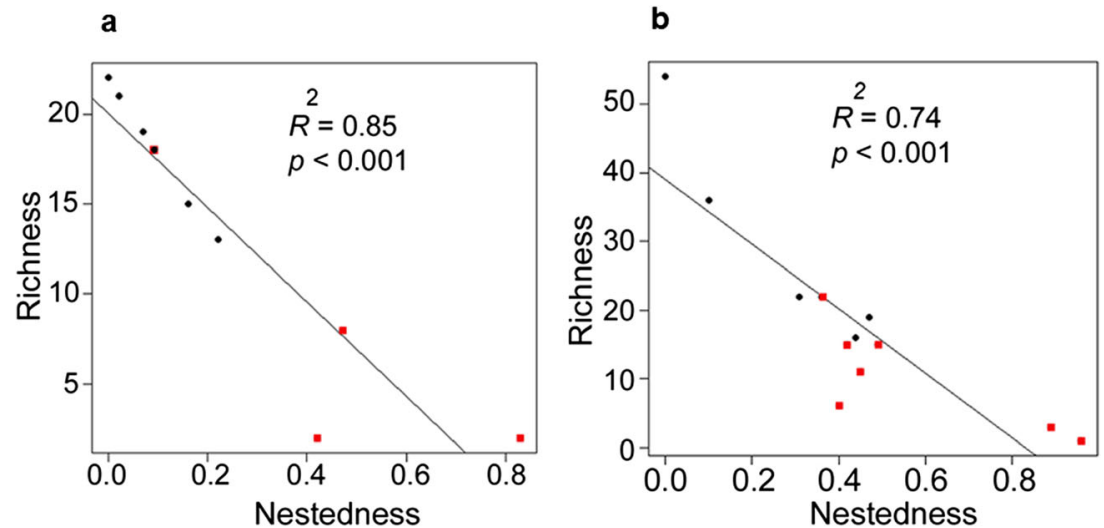
distribution, and the analysis of the $\mathrm{C}$-score indicated that the species composition pattern was non-random. However, our contrasting results among NODF (nestedness significant) and $\mathrm{C}$-score indices (isolation significant) may be attributed to the long isolation of sites, the effect of human activities, and the likely resistance of the matrix surrounding the urban sites. It is possible that external factors, such as habitat quality and species attributes are influencing the pattern of nestedness (Butaye et al. 2001). An association between nestedness and isolation has been found in other studies (see Meyer and Kalko 2008), possibly because is related to habitat quality (Kadmon 1995).

Our results from $\mathrm{C}$-scores index showed that species composition is different from those generated randomly. This result suggests that this nested pattern is related to the regional pool of species, and species are isolated in PAs within urban matrix. However, the small PAs in urban matrix may not safeguard some species for long time due to small population size, high predation rate, and high pollution level (Lengagne 2008; Herrera-Montes and Aide 2011; Francis and Barber 2013). Moreover, it is likely that corridors are ineffective as dispersal routes for many species, mainly those in urban matrix. Therefore, we suggest that the observed pattern among the anuran communities of this study may also reflect environmental filters that restrict the distribution of species due to anthropogenic changes.

It is important to emphasize the presence of the forestspecialist Haddadus binotatus in an urban matrix site of Maringá (i.e., Parque dos Pioneiros - PPi). This species was considered rare in this municipality and differs from most other species by having direct development on the forest leaf-litter (Hedges et al. 2008). In both study localities Haddadus binotatus was only found in PAs that had been only partially altered (i.e., selective logging, earthmoving). Regarding Maringá, most forest areas were substantially altered.

In São Paulo, Adenomera marmorata was the only species recorded in an urban matrix site (i.e., Parque Tentente Siqueira Campos "Trianon MASP"- PTSC). This species does not use water bodies for breeding but lays its eggs in subterranean chambers where endotrophic tadpoles develop until >metamorphosis (Heyer et al. 1990). Although this area is a remnant of native vegetation, it is located in the center of São Paulo city and there are no connections to fragments, and thus it has been completely isolated for over a century (Malagoli 2008).

The betapart results indicated that the sites with greater species richness (inserted in non-urban matrix) act similarly and positively in the nesting pattern in both regions. This suggested that the global network of points between sites have greater importance in the structure of communities and not only the point of greatest species richness. Most species from the urban matrix sites are likely to be more resistant to environmental changes because they are considered open area dwellers. For instance, species dependent on forest environments and preserved sites, such as Crossodactylus schmidti and Bokermannohyla astartea, were not recorded in urban matrix sites. The absence of these species in urban matrix sites may indicate their dependence on forest for maintaining viable population. Moreover, other habitat-specialist species were only found in non-urban matrix sites (Malagoli 2008, 2013; present study), such as Vitreorana uranoscopa and Hylodes
Fig. 6 Box plot showing the mean area of PAs (size in Ha) from Urban to Non-Urban matrix for (a) Maringá and (b) São Paulo with Mann-Whitney test; (c) Maringá and (d) São Paulo, showing the mean richness of PAs located in the oldest urbanized areas, periphery of urban matrix and non-urban areas
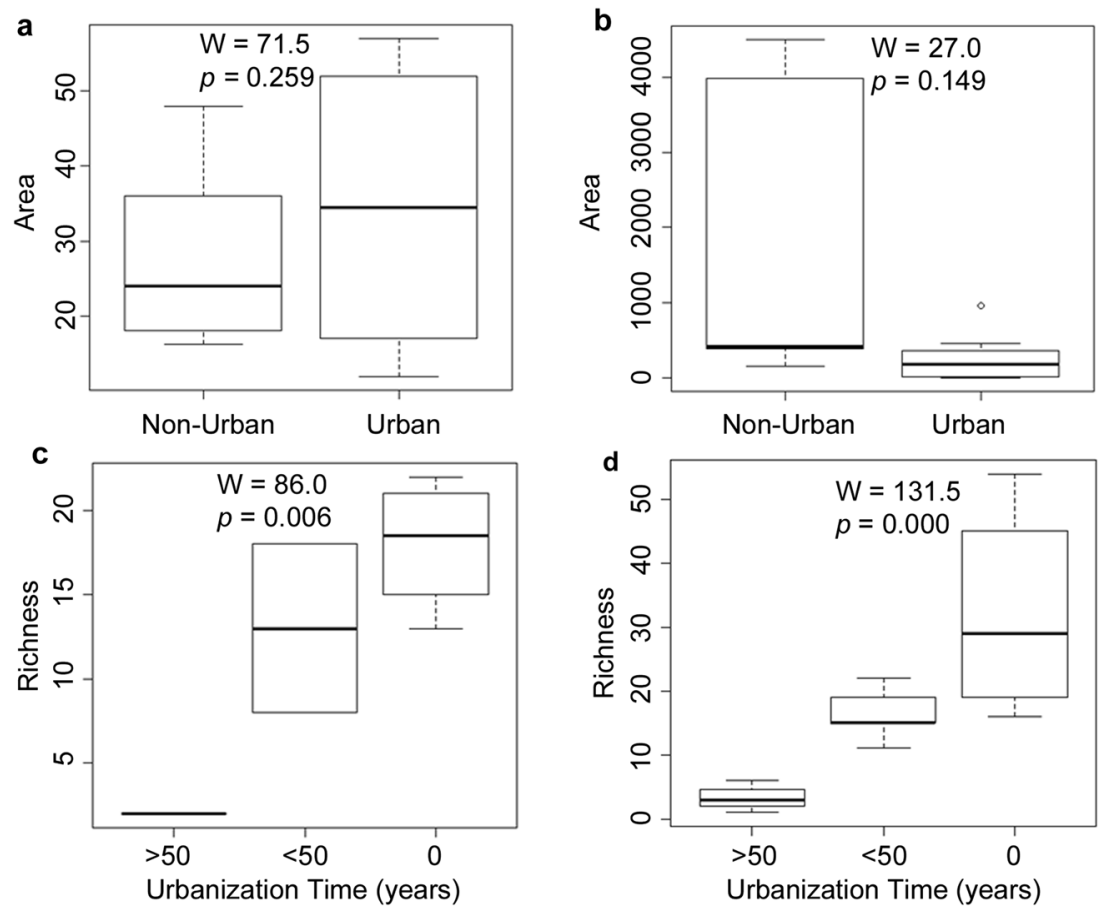
phyllodes that require clean freshwater in streams for larval development, and Dendrophryniscus brevipollicatus and Bokermannohyla astartea, that lay eggs in large bromeliads (Malagoli 2008; Haddad et al. 2013).

Large PAs within the urban matrix of the municipality of Maringá have lower species richness when compared to PAs of all sizes in the non-urban matrix (PI 47.4 ha and PPi $57.3 \mathrm{ha}$ ). This pattern suggests that the location and the conservation status of these sites are possibly more important for the occurrence of most species than the size of the fragment. In São Paulo, PESMCu and PEC are non-urban matrix sites that are much larger than other PAs. Additionally, these areas are connected to other forest remnants (e.g., PESMCu is part of Serra do Mar State Park, the largest PA in the Atlantic Forest of São Paulo State with ca. 327,000 ha) that may have high habitat quality that facilitates greater species persistence. However, populations remaining isolated in the urban matrix (i.e., Adenomera marmorata in PTSC) may be suffering from reproductive isolation and subjected to factors that reduce their long-term persistence due to increasing inbreeding and genetic drift (see Dixo et al. 2009). In addition, species with terrestrial development (i.e., H. binotatus and A. marmorata, respectively) are more susceptible to the negative effects of the chytridiomycosis (Mesquita et al. 2017). Considering that these species seem to persist in urban matrix (e.g., PPi and PTSC), they may be more susceptible to both isolation and chytrid fungus. Even anurans from PAs in the periphery of urban matrix may be affected by urbanization. We recommend further study in these areas, analyzing if those species are suffering from genetic isolation.

Patterns of nested assemblages of anurans are strongly influenced by the sensitivity of individual species to altered habitat (Cook et al. 2004). Most anurans are sensitive to environmental changes, and especially to changes in their breeding site, which may result in their extinction from a particular location (Gerson 2012). For example, acoustic communication is an important aspect of anuran social interactions, including reproduction (Wells 2007). Proximity to urban environments can result in noise pollution, which can affect the acoustical context of anuran social interactions and thus their persistence in an environment (Bee and Swanson 2007; Hoskin and Goosem 2010; Goutte et al. 2013).

Some studies have related the type of matrix habitat to the susceptibility for extinction (Henle et al. 2004; Watling and Donnelly 2007). Amphibians generally have low rates of colonization and association to matrix (Watling et al. 2009; Almeida-Gomes and Rocha 2014; Lourenço-de-Moraes et al. 2014; Ferreira et al. 2016). Factors, such as susceptibility to water loss by evaporation can affect amphibian dispersion among habitat patches (Young et al. 2005, 2006; Becker et al. 2007; Tracy et al. 2008; Watling et al. 2009). Additionally, some PAs are disconnected from water bodies (i.e., habitat split), which increases the negative effect on anurans with biphasic life cycles (Becker et al. 2007; Ferreira et al. 2010, 2012, 2016) and are more susceptible to invasive and domestic species (e.g., Lithobates catesbeianus and cats) that prey on native anurans (Silva et al. 2011; RLM pers. obs.).

Information related to habitat quality and how environmental characteristics (e.g., predation and pollution) may affect anurans are vital to making decisions that maximize their protection. Our results contribute to the understanding of the distribution of anurans among urban and non-urban matrix sites in the Neotropics and provide some relevant considerations for the management of protected areas, especially those in urban environments. The urbanization time had a dramatic negative effect on the anurans. The Revitalization strategies, adjustment and maintenance (as quality of reproductive environments and effective corridors) of protected areas in urban matrix are necessary for the conservation of Neotropical anurans.

Acknowledgements We are thankful to Nadson R. Simões for providing valuable comments on the manuscript, and Uningá and UniCesumar for providing financial support for fieldwork. We thank Hussam Zaher and Taran Grant (MZUSP), and Luis Felipe Toledo (ZUEC) for allowing examination of material under their care. SEMAA (Secretaria do Meio Ambiente e Agricultura) de Maringá and Divisão Técnica de Medicina Veterinária e Manejo de Fauna Silvestre (DEPAVE-3/SVMA/PMSP) for logistical support in the early stages of this work. We are very grateful to the anonymous reviewers, and the editors, for suggestions that improved this manuscript. Erik Wild improved our use of English. RLM (140710/ 2013-2; 152303/2016-2), RBF (231020/2013-9), LRM (141259/2014-0), RPB and RJS thank CNPq (Conselho Nacional de Desenvolvimento Cientifico e Tecnológico) for scholarships. VB and IPA thank CAPES (Coordenação de Aperfeiçoamento de Pessoal de Nível Superior) and PROEX (Programa de Excelência Acadêmica) for scholarships. RBF thanks the Ecology Center at Utah State University and CAPES for scholarships. LRM, RJS, and CFBH (2008/50928-1; 2008/54472-2; 2013/50741-7; 2014/23677-9) thank FAPESP (São Paulo Research Foundation). LRM thank COTEC/IF (40.452/2004; 40.574/2006) for the sampling permits. RJS thanks FADA-UNIFESP for research fellowships. We thank ICMBio (Instituto Chico Mendes de Conservação da Biodiversidade) for collection permits (076/06, 032/2005, 019/07, 16350-1, 54085-1 and 088/07).

\section{References}

Almeida-Gomes M, Rocha CFD (2014) Habitat loss reduces the diversity of frog reproductive modes in an Atlantic forest fragmented landscape. Biotropica 47:113-118

Almeida-Neto M, Guimarães P, Guimarães PR Jr, Loyola RD, Ulrich W (2008) A consistent metric for nestedness analysis in ecological systems: reconciling concept and measurement. Oikos 117:12271239

Baselga A (2010) Partitioning the turnover and nestedness components of beta diversity. Glob Ecol Biogeogr 19:134-143

Baselga A, Orme CDL (2012) Betapart: an R package for the study of beta diversity. Methods Ecol Evol 3:808-812

Becker CG, Fonseca CR, Haddad CFB, Batista RF, Prado PI (2007) Habitat split and the global decline of amphibians. Science 318: $1775-1777$ 
Bee MA, Swanson EM (2007) Auditory masking of anuran advertisement calls by road traffic noise. Anim Behav 74:1765-1776

Butaye J, Jacquemyn H, Hermy M (2001) Differential colonization causing non-random forest plant community structure in a fragmented agricultural landscape. Ecography 24:369-380

Cadotte MW, Mai DV, Jantz S, Collins MD, Keele M, Drake JA (2006) On testing the competition-colonization tradeoff in a multispecies assemblage. Am Nat 168:704-709

Cook R, Quinn JF (1995) The influence of colonization in nested species subsets. Oecologia 102:413-424

Cook RR, Quinn JF (1998) An evaluation of randomization models for nested species subsets analysis. Oecologia 113:584-592

Cook RR, Angermeier P, Finn D, Poff N, Krueger K (2004) Geographic variation in patterns of nestedness among local stream fish assemblages in Virginia. Oecologia 140:639-649

Corn P (1994) Straight line drift fences and pitfall traps. In: Heyer WR, Donnelly MA, McDiarmid RW, Hayek LAC, Foster MS (eds) Measuring and monitoring biological diversity: standard methods for amphibians, Smithsonian Institution Press, Washington DC, pp $109-117$

Crump ML, Scott Jr NJ (1994) Visual encounter surveys. In: Heyer WR, Donnelly MA, McDiarmid RW, Hayek LAC, Foster MS (eds) Measuring and monitoring biological diversity: standard methods for amphibians, Smithsonian Institution Press, Washington DC, pp $84-92$

Dixo M, Metzger JP, Morgante JS, Zamudio KR (2009) Habitat fragmentation reduces genetic diversity and connectivity among toad populations in the Brazilian Atlantic coastal Forest. Biol Conserv 142: 1560-1569

Ferreira RB, Silva-Soares T, Rödder D (2010) Amphibians of Vitória, an urban area in South-Eastern Brazil: first approximation. Salamandra 46:187-196

Ferreira RB, Dantas RB, Tonini JFR (2012) Distribuição espacial e sazonal de anfíbios em quatro poças na região serrana do Espírito Santo, sudeste do Brasil: influência de corredores florestais. Iheringia 102:163-169

Ferreira RB, Beard KH, Crump ML (2016) Breeding guild determines frog distributions in response to edge effects and habitat conversion in the Brazil's Atlantic Forest. PLoS One 11(6):e0156781

Francis CD, Barber JR (2013) A framework for understanding noise impacts on wildlife: an urgent conservation priority. Front Ecol Environ 11:305-313

Frost DR (2017) Amphibian species of the world: an online reference. Version 6.0 (27 November 2017). Electronic Database accessible at http://research.amnh.org/herpetology/amphibia/index.html. American Museum of Natural History, New York, USA

Gaston KJ, Blackburn TM (2000) Pattern and process in macroecology. Blackwell Science, Oxford

Gerson H (2012) International trade in amphibians: a customs perspective. Alytes 29:103-115

Gilpin ME, Hanski I (1991) Metapopulation dynamics: empirical and theoretical investigations. Biol J Linn Soc 42:1-336

Gotelli NJ, Graves GR (1996) Null models in ecology. Smithsonian Institution Press, Washington

Goutte S, Dubois A, Legendre F (2013) The importance of ambient sound level to characterise anuran habitat. PLoS One 8(10):e78020

Haddad CFB, Toledo LF, Prado CPA, Loebmann D, Gasparini JL, Sazima I (2013) Guia dos anfíbios da Mata Atlântica: diversidade e biologia. Anolis Books, São Paulo

Hedges SB, Duellman WE, Heinicke MP (2008) New world directdeveloping anurans (Anura: Terrarana): molecular phylogeny, classification, biogeography, and conservation Zootaxa 1737:1-182

Henle K, Davies KF, Kleyer M, Margulues C, Settele J (2004) Predictors of species sensitivity to fragmentation. Biodivers Conserv 13:207251
Herrera-Montes MI, Aide TM (2011) Impacts of traffic noise on anuran and bird communities. Urban Ecosyst 14:415-427

Heyer WR, Rand AS, Cruz CAG, Peixoto OL, Nelson CE (1990) Frogs of Boracéia. Arq Zool 31:231-410

Hoffmann MC, Hilton-Taylor A et al (2010) The impact of conservation on the status of the world's vertebrates. Science 330:1503-1509

Hoskin CJ, Goosem MW (2010) Road impacts on abundance, call traits, and body size of rainforest frogs in Northeast Australia. Ecol Soc. http://www.ecologyandsociety.org/vol15/iss3/art15/. Accessed 9 July

IUCN (2016) IUCN Red list of threatened species. Version 2014.3. www. iucnredlist.org. Accessed 6 March 2017

Kadmon R (1995) Nested species subsets and geographic isolation: a case study. Ecology 76:458-465

Lambert MRK (1997) Effects of pesticides on amphibians and reptiles in sub-Saharan Africa. Rev Environ Contam T 150:31-73

Legendre P, Anderson MJ (1999) Distance-based redundancy analysis: testing multispecies responses in multifactorial ecological experiments. Ecol Monogr 69:1-24

Legendre P, Fortin MJ (1989) Spatial pattern and ecological analysis. Vegetatio 80:107-138

Leibold MA, Mikkelson GM (2002) Coherence, species turnover, and boundary clumping: elements of meta-community structure. Oikos 97:237-250

Leibold MA, Holyoak M, Mouquet N, Amarasekare P, Chase JM, Hoopes MF, Holt RD, Shurin JB, Law R, Tilman D, Loreau M, Gonzalez A (2004) The metacommunity concept: a framework for multi-scale community ecology. Ecol Lett 7:601-613

Lengagne $\mathrm{T}$ (2008) Traffic noise affects communication behaviour in a breeding anuran, Hyla arborea. Biol Conserv 141:2023-2031

Lips KR, Donnelly MA (2002) What the tropics can tell us about declining amphibian populations: current patterns and future prospects. In: Lannoo MJ (ed) North American amphibians: status and conservation. University of Chicago Press, USA, pp 388-406

Lomolino MV (1996) Investigating causality of nestedness of insular communities: selective immigration or extinction. J Biogeogr 23: 699-703

Lomolino MV (2000) A species-based theory of insular zoogeography. Glob Ecol Biogeogr 9:39-58

Lourenço-de-Moraes R, Ferreira RB, Fouquet A, Bastos RP (2014) A new diminutive frog species of Adelophryne (Amphibia: Anura: Eleutherodactylidae) from the Atlantic Forest, southeastern Brazil. Zootaxa 3846:348-360

Maack R (1981) Geografia física do Estado do Paraná. José Olympio, Rio de Janeiro

Malagoli LR (2008) Anfíbios do município de São Paulo: histórico, conhecimento atual e desafios para a conservação. In: Malagoli LR, Bajesteiro FB, Whately M (eds) Além do concreto: contribuições para a proteção da biodiversidade paulistana. São Paulo, Instituto Socioambiental, pp 204-231

Malagoli LR (2013) Diversidade e distribuição dos anfíbios anuros do Núcleo Curucutu, Parque Estadual da Serra do Mar, SP. Master thesis, Universidade Estadual Paulista, Instituto de Biociências, Rio Claro, SP

Mesquita AFC, Lambertini C, Lyra M, Malagoli LR, James TY, Toledo LF, Haddad CFB, Becker CG (2017) Low resistance to chytridiomycosis in direct-developing amphibians. Sci Rep 7: 16605. https://doi.org/10.1038/s41598-017-16425-y

Meyer CFJ, Kalko EKV (2008) Bat assemblages on Neotropical landbridge islands: nested subsets and null model analyses of species cooccurrence patterns. Divers Distrib 14:644-654

Mittermeier RA, Gil PR, Hoffman M, Pilgrim J, Brooks T, Mittermeier CG, Lamoreux J, Fonseca GAB (2004) Hotspots revisited: earth's biologically richest and most endangered terrestrial ecoregions. CEMEX \& Agrupacion Sierra Madre, Cidade do México 
Moore JE, Swihart RK (2007) Importance of fragmentation-tolerant species as seed dispersers in disturbed landscapes. Oecologia 151:663674

Moreira LFB, Maltchik L (2012) Assessing patterns of nestedness and co-occurrence in coastal pond anuran assemblages. AmphibiaReptilia 33:261-271

Morrison LW (2013) Nestedness in insular floras: spatiotemporal variation and underlying mechanisms. J Plant Ecol-UK 6:480-488

Oksanen J, Kindt R, Legendre P, O'Hara B, Stevens MHH (2007) Vegan: community ecology package. $\mathrm{R}$ package, version $1.8-8$

Olson DM, Dinerstein E, Wikramanayake ED, Burgess ND, Powell GVN, Underwood EC, D'Amico JA, Itoua I, Strand HE, Morrison JC, Loucks CJ, Allnutt TF, Ricketts TH, Kura Y, Lamoreux JF, Wettengel WW, Hedao P, Kassem KR (2001) Terrestrial ecoregions of the world: a new map of life on earth. Bioscience 51:933-938

Patterson BD, Atmar W (1986) Nested subsets and the structure of insular mammalian faunas and archipelagos. In: Heaney LR, Patterson BD (eds) Island biogeography of mammals. Academic Press, London, pp 65-82

Patterson BD, Brown JH (1991) Regionally nested patterns of species composition in granivorous rodent assemblages. J Biogeogr 18: 395-402

Peel MC, Finlayson BL, Mcmahon TA (2007) Updated world map of the Köppen-Geiger climate classification. Hydrol Earth Syst Sci 11: 1633-1644

R Core Team (2017) R: A language and environment for statistical computing. R Foundation for Statistical Computing, Vienna, Austria

Ribeiro MC, Metzger JP, Martensen AC, Ponzoni FJ, Hirota MM (2009) The Brazilian Atlantic Forest: how much is left, and how is the remaining forest distributed? Implications for conservation. Biol Conserv 142:1141-1153

Rocha CFD, Vrcibradic D, Kiefer MC, Menezes VA, Fontes AF, Hatano FH, Galdino CAB, Bergallo HG, Van Sluys M (2014) Species composition, richness and nestedness of lizard assemblages from Restinga habitats along the brazilian coast. Braz J Biol 74(2):349 354

Rödder D, Teixeira RL, Ferreira RB, Dantas RB, Pertel W, Guarneire GJ (2007) Anuran hotspots: the municipality of Santa Teresa, Espírito Santo, southeastern Brazil. Salamandra 43:91-110

Segalla MV, Caramaschi U, Cruz CAG, Grant T, Haddad CFB, Langone J Garcia PCA (2016) Brazilian amphibians: list of species. http:// www.sbherpetologia.org.br/images/LISTAS/Lista_Anfibios2016. pdf. Accessed 28 January 2017
Silva TE, Ribeiro Filho OP, Feio RN (2011) Predation of native anurans by invasive bullfrogs in southeastern Brazil: spatial variation and effect of microhabitat use by prey. S Am J Herpetol 6(1):1-10

Stuart SN, Chanson JS, Cox NA, Young BE, Rodrigues ASL, Fischman DL, Waller RW (2004) Status and trends of amphibian declines and extinctions worldwide. Science 306:1783-1786

Taylor CM, Warren ML (2001) Dynamics of species composition of stream fish assemblages: environmental variability and nested subsets. Ecology 82:2320-2330

Tockner K, Klaus I, Baumgartner C, Ward JV (2006) Amphibian diversity and nestedness in a dynamic floodplain river (Tagliamento, NEItaly). Hydrobiologia 565:121-133

Tracy CR, Christian KA, Betts G, Tracy CR (2008) Body temperature and resistance to evaporative water loss in tropical Australian frogs. Comp Biochem Physiol A 150:102-108

Ulrich W, Gotelli NJ (2007) Null model analysis of species nestedness patterns. Ecology 88:1824-1831

Ulrich W, Almeida-Neto M, Gotelli NJ (2009) A consumer's guide to nestedness analysis. Oikos 118:3-17

Watling JI, Donnelly MA (2007) Multivariate correlates of extinction proneness in a naturally fragmented landscape. Divers Distrib 13: 372-378

Watling JI, Gerow K, Donnelly MA (2009) Nested species subsets of amphibians and reptiles on Neotropical forest islands. Anim Conserv 12:467-476

Wells KD (2007) The ecology and behavior of amphibians. University of Chicago Press

Wilson DS (1992) Complex interactions in metacommunities, with implications for biodiversity and higher levels of selection. Ecology 73:1984-2000

Wright DH, Reeves JH (1992) On the meaning and measurement of nestedness of species assemblages. Oecologia 92:416-428

Young JE, Christian KA, Donnellan S, Tracy CR, Parry D (2005) Comparative analysis of cutaneous evaporative water loss in frogs demonstrates correlation with ecological habits. Physiol Biochem Zool 78:847-856

Young JE, Tracy CR, Christian KA, McArthur LJ (2006) Rates of cutaneous evaporative water loss of native Fijian frogs. Copeia 2006:8388

Zimmerman BL (1994) Audio strip transects. In: Heyer WR, Donnelly MA, McDiarmid RW, Hayek LAC, Foster MS (eds) Measuring and monitoring biological diversity: standard methods for amphibians, Smithsonian Institution Press, Washington DC, pp 92-97 